\title{
Relationship of Abdominal Circumference, BMI and Sweet Food Consumption with Diabetes Mellitus in Adults 26-45 Years Old in DKI Jakarta (Riskesdas 2018 Analysis)
}

\author{
Hubungan Lingkar Perut, IMT dan Konsumsi Makanan Manis dengan Kejadian \\ Diabetes Mellitus Pada Orang Dewasa Usia 26-45 Tahun di DKI Jakarta \\ (Analisis Riskesdas 2018)
}

\section{Anisa Putri Etika Ramadena1*, Sintha Fransiske Simanungkalit ${ }^{1}$, A'immatul $^{\prime}$ Fauziyah ${ }^{1}$}

\author{
${ }^{1}$ Nutrition Study Program, Universitas Pembangunan Nasional Veteran Jakarta, Jakarta, Indonesia \\ *Email corresponding author: anisaputrietikar@upnvj.ac.id
}

\begin{abstract}
Diabetes mellitus occurs, one of which is characterized by hyperglycemia that occurs due to insulin abnormalities or insulin action (Perkeni, 2015). The 2018 Riskesdas survey showed an increase in the prevalence of diabetes mellitus in people over 15 years of age. High carbohydrate intake can affect the incidence of diabetes mellitus. This is caused carbohydrates that have been broken down by the body into glucose will be circulated throughout the body and the glucose balance will be controlled by the pancreas by releasing the hormone insulin. If a insulin produced is few, the glucose level in the blood will be excess and increase the occurrence of hyperglycemia. This study aims to analyze the relationship between consumption of sweet foods, body mass index and abdominal circumference with the incidence of diabetes mellitus in adults aged 26-45 years in DKI Jakarta based on the Riskesdas 2018 analysis. The results of the bivariate test with chi square showed a relationship between consumption of sweet foods $(p=0,000)$, body mass index $(p=0,000)$ and abdominal circumference $(p=0,000)$ with the incidence of diabetes mellitus. It can be concluded that there is a relationship between consumption of sweet foods, body mass index and abdominal circumference with the incidence of diabetes mellitus in adults aged 26-45 years in DKI Jakarta.
\end{abstract}

Key Words: adults, abdominal circumference, BMI, diabetes mellitus, sweet foods

\section{INTRODUCTION}

Diabetes mellitus is a group of metabolic disease caused by abnormalities in insulin and insulin action or both (American Diabetes Association, 2010). If not treated properly, diabetes can lead to other diseases that can be serious (Goldberg, 2007 in Garnita, 2012 in Infodatin Ministry of Health, 2018). The results of research conducted by the Ministry of Health of the Republic of Indonesia, namely the Basic Health Research (Riskesdas) in 2013 showed the results, nationally the prevalence of people with diabetes mellitus in the population aged $>15$ years was $6.9 \%$ and in the 2018 Riskesdas results (Riskesdas, 2018 Litbangkes) the national prevalence of people with diabetes mellitus aged $>15$ years was $8.5 \%$. Nationally, DKI Jakarta ranks first in the 2018 Riskesdas for the incidence of diabetes mellitus based on the category of diabetes with a doctor's diagnosis with $>15$ years of age or all ages.

Asil, E et al., 2014 explain is obesity of a person can be known through measurement of body mass index (BMI). BMI is also an indicator that is often used in determining the level of nutritional status in adults. However, BMI is not the only indicator that can judge someone's excess or not. This is influenced by several factors, namely gender, genetics, age, 
diet, and physical activity. Noor R, 2015 explain is one of the factors that influence the occurrence of diabetes is abdominal circumference that exceeds the normal limit because a person will experience obesity. Insulin resistance in the body can occur in someone who is overweight. This is due to the accumulation of fat in the bloodstream which causes glucose to be unable to circulate throughout the body. Because there is a buildup, the body cannot process glucose into energy, as a result, diabetics often feel weak and often sleepy.

Diabetes usually occurs in adulthood, but it is undeniable that diabetes can also happen to anyone, the only difference being how diabetes occurs. This is because people generally pay less attention to their diet and health. One of the causes is frequent consumption of sweet foods and lack of physical activity. Identification and treatment of risk factors for diabetes mellitus must be carried out in adulthood to prevent the occurrence of complications that are more dangerous at a later age.

\section{METHODS}

This research is a quantitative research with aresearch design cross sectional. The population in this study all male and female adults aged 26-45 years located in DKI Jakarta and a sample of 216 respondents with sample calculations using the two-proportion difference test formula (Notoatmojo, 2012).

$$
n=\frac{\left(z_{1}-\frac{\alpha}{2} \sqrt{2 p(1-P)}+z_{1-\beta} \sqrt{P 1(1-P 1)+P 2(1-P 2)}\right)^{2}}{(P 1-P 2)^{2}}
$$

The sampling procedure carried out by the researcher was seen based on the inclusion and exclusion criteria. The inclusion criteria determined by the researcher were respondents in the DKI Jakarta area, aged 26-45 years, male and female. Meanwhile, the exclusion criteria are having comorbidities and incomplete respondent data. Then the researcher cleared the data by looking at the data provided by the Laboratory of Management and Data Analysis of the Ministry of Health of the Republic of Indonesia and calculating it using computer software.

The research was carried out after obtaining permission from the Health Research Ethics Committee of UPN "Veteran" Jakarta with letter number: 87/I/2021/KEPK.

\section{RESULTS AND DISCUSSION}

In this study using secondary data obtained from the Laboratory of Management and Data Analysis of the Ministry of Health of the Republic of Indonesia. At the beginning of the data obtained as much as 3,755,623 data and after clearing the data obtained data as much as 3,557,517 data. Because the data required by the researcher has exceeded the number of samples required, which is as many as 216 respondents, the researcher decided to use all existing data. With the following: 
Table 1 Characteristics of Respondents

\begin{tabular}{lcc}
\hline \multicolumn{1}{c}{ Characteristics } & $\mathbf{n}$ & $\mathbf{( \% )}$ \\
\hline Gender & & \\
$\quad$ Male & 1.842 .941 & 51,5 \\
Female & 1.724 .576 & 48,5 \\
\hline Age & & \\
$\quad$ Early Adulthood (26-35 years) & 1.897 .035 & 53,3 \\
$\quad$ Late Adult (36-45 years) & 1.660 .482 & 46,7 \\
\hline Diabetes Mellitus & & \\
$\quad$ Yes & 40.892 & 1,1 \\
$\quad$ No & 3.516 .625 & 98,9 \\
\hline
\end{tabular}

All of the total respondents, $51.5 \%$ of the respondents were male and $53.3 \%$ of the respondents belonged to the category of early adulthood. On examination, DM is determined in various ways, one of which is by a doctor's diagnosis and reinforced by the presence of classical complaints. Of the total respondents, $1.1 \%$ suffer from DM which is determined based on a doctor's diagnosis. Consumption of sweet food for all respondents can be seen in the following table:

Table 2 Proportion of Consumption Sweet Food

\begin{tabular}{lcc}
\hline \multicolumn{1}{c}{ Frequency of Eating } & n & (\%) \\
\hline$<3$ times per month & 418.330 & 11,8 \\
1 time per day & 1.095 .391 & 30,8 \\
$3-6$ times per week & 790.963 & 22,2 \\
1 - times per week & 1.091 .090 & 30,7 \\
Never & 161.743 & 4,5 \\
\hline
\end{tabular}

The highest result of respondents consuming sweet foods was 1 time per day by $30.8 \%$ and the lowest in the never category at $4.5 \%$. Research conducted by Susilowati and Waskita (2019) on outpatients at the Madiun Hospital found that 61 respondents consumed sweet foods. There are four categories in BMI nutritional status, namely underweight (BMI $<18.5 \mathrm{~kg} / \mathrm{m} 2$ ), normal (BMI $18.5-<25 \mathrm{~kg} / \mathrm{m} 2$ ), overweight (BMI $25-<27 \mathrm{~kg} / \mathrm{m} 2$ ) and obesity (BMI $27 \mathrm{~kg} / \mathrm{m} 2$ ). The following are the results of statistical analysis:

Table 3 Nutritional Status based on BMI

\begin{tabular}{lcc}
\hline \multicolumn{1}{c}{ Category Nutritional Status } & $\mathbf{n}$ & $\mathbf{( \% )}$ \\
\hline Underweight & 248.938 & 7 \\
Normal & 1.639 .303 & 46,1 \\
Overweight & 519.620 & 14,6 \\
Obesity & 1.149 .656 & 32,3 \\
\hline
\end{tabular}

Respondents who have normal nutritional status are 46.1\%. Meanwhile, the least prevalence is in the underweight category at 7\%. Research conducted by Amir, Wungow and Pangemanan (2015) stated the same thing, namely as many as 10 respondents $(45.5 \%)$ had normal BMI values and for prevalence the least was in the category underweight as many as 1 respondent (4.5\%).

Measurement of a person's abdominal circumference is divided into two based on gender. The normal limit for female abdominal circumference is $80 \mathrm{~cm}$ and for men it is 90 $\mathrm{cm}$. If a person's abdominal circumference measurement exceeds the normal limits that have been set, it is included in the category of central obesity. 
Table 4 Nutritional Status based in Abdominal Circumference

\begin{tabular}{lcccc}
\hline \multirow{2}{*}{ Gender } & \multicolumn{2}{c}{ Normal } & \multicolumn{2}{c}{ Central Obesity } \\
\cline { 2 - 5 } & $\mathbf{n}$ & $\mathbf{( \% )}$ & $\mathbf{n}$ & $\mathbf{( \% )}$ \\
\hline Male & 1.323 .616 & 72,2 & 509.325 & 27,8 \\
Female & 729.884 & 42,3 & 994.692 & 57,7 \\
\hline
\end{tabular}

The calculation results obtained $27.8 \%$ in men and $57.7 \%$ in women included in the central obesity. Research conducted by Perwitasari, Prabowo and Susanti (2017) which was conducted in late adolescence showed that the majority of respondents were included in the normal abdominal circumference category in both sexes as many as 119 respondents $(87.5 \%)$ and 17 respondents in the central obesity category $(12.5 \%)$ in both gender.

\section{Gender and The Incidence of Diabetes Mellitus}

Table 5 Relationship between Gender and The Incidence of Diabetes Mellitus

\begin{tabular}{lccc}
\hline \multirow{2}{*}{ Category } & \multicolumn{2}{c}{ Diabetes Mellitus } & \multirow{2}{*}{$\boldsymbol{p}$ value } \\
\cline { 2 - 3 } & Yes & No & \\
\cline { 2 - 3 } Male & 14.798 & 1.818 .144 & 0,00 \\
Female & 26.094 & 1.698 .482 & \\
\hline
\end{tabular}

Table 5 shows that the result $p$ value $=0,00$ which means that there is a significant relationship between gender and the incidence of diabetes mellitus in people aged 26-45 years old in DKI Jakarta. In another study showed the same results, women are more at risk of suffering from diabetes mellitus. This is because women have a higher body fat composition (Trisnawati, 2013). This is due to the mechanism of hormonal changes that occur and cause women to experience hyperandrogen conditions. Meyer et al. (2011) stated that physically women are more at risk for diabetes mellitus because they have a greater chance of increasing body mass index (BMI) and central obesity.

Central obesity causes an increase in catecholamines which can cause lipolysis. In adipose tissue, a person with central obesity may be larger in size and less sensitive to antrilipolysis. This antilipolysis causes an increase in free fatty acids (FFA) at the time of lipolysis. Excess FFA causes muscle glucose utilization to decrease while liver glucose production increases. The excess free fatty acids cause translocation of GLUT 4 in the cell membrane so that glucose cannot be channeled into cells which results in insulin disruption (Wisadtra, et.al, 2015).

\section{Age with The Incidence of Diabetes Mellitus}

Table 6 Relationship between Gender and The Incidence of Diabetes Mellitus

\begin{tabular}{lccc}
\hline \multirow{2}{*}{ Category } & \multicolumn{2}{c}{ Diabetes Mellitus } & \multirow{2}{*}{ p value } \\
\cline { 2 - 3 } & Yes & No & \multirow{2}{*}{0.00} \\
\hline Early Adult & 7.825 & 1.889 .211 & \\
Late Adult & 33.067 & 1.627 .415 & \\
\hline
\end{tabular}

Table 6 shows that the result $p$-value $=0.000$. This shows that there is a significant relationship between a person's age and the incidence of diabetes mellitus in people aged 26-45 years in DKI Jakarta.

A study conducted by A. Pahlawati (2019) showed the same results, namely age was positively related to the incidence of diabetes mellitus. Kekenusa, Ratag and Wuwungan (2013) in their research stated that age is not the only thing that causes a person to be diagnosed with diabetes mellitus because as many as $20 \%$ of respondents suffer from diabetes mellitus before the age of 45 years. 
Research conducted in Bogor by Sirait et al. (2015) stated that the older a person gets, the greater the occurrence of hyperglycemia resulting from a decrease in the work of the pancreas to produce insulin.

\section{Consumtion of Sweet food with The Incidence}

Table 7 Relationship between Consumption of Sweet Food with The Incidence of Diabetes Mellitus

\begin{tabular}{lccc}
\hline \multirow{2}{*}{ Category } & \multicolumn{2}{c}{ Diabetes Mellitus } & \multirow{2}{*}{ p value } \\
\cline { 2 - 3 } & Yes & No & \multirow{2}{*}{0,00} \\
\hline Often & 13.862 & 1.081 .529 & \\
Rarely & 27.030 & 2.435 .096 & \\
\hline
\end{tabular}

The table shows the results of $p$-value $=0.000$ which means that there is a significant relationship between the consumption of sweet foods and the incidence of diabetes mellitus in people aged 26-45 years in DKI Jakarta. This is supported by research conducted by Kahlhöfer et al. (2016) which shows a positive relationship between consumption of sweet foods and blood glucose levels.

Another study conducted by Radio (2011) showed that someone who has a habit of consuming sweet foods will have a twice greater risk of developing diabetes mellitus. This is because when a person consumes sweet foods, it stimulates the pancreas to produce insulin, which converts sugar into energy. When the pancreas releases insulin, at the same time insulin will also inhibit the production of the hormone leptin so that the brain gets a signal that we are full. However, if there is insulin resistance in a person's body, it causes insulin to not be able to inhibit the production of the hormone leptin and the pancreas will continue to produce insulin, so that a person will continue to feel hungry even though he has consumed a lot of food.

\section{Body Mass Index with The Incidence of Diabetes Mellitus}

The table shows the $\mathrm{p}$-value $=0.000$. This means that there is a significant relationship between BMI and the incidence of diabetes mellitus in people aged 26-45 years in DKI Jakarta.

Table 8 Relationship between BMI and The Incidence of Diabetes Mellitus

\begin{tabular}{lccc}
\hline \multirow{2}{*}{ Nutritional Status } & \multicolumn{2}{c}{ Diabetes Mellitus } & \multirow{2}{*}{ p value } \\
\cline { 2 - 3 } & Yes & No & \\
\hline Normal & 15.455 & 1.863 .185 & \multirow{2}{*}{0,00} \\
Fat & 25.436 & 1.643 .839 & \\
\hline
\end{tabular}

Research conducted by Devy (2017) shows that there is a correlation between BMI and blood sugar levels, where the greater the value of the BMI calculation results, the higher a person's blood sugar level. Andyana et al. (2020) explained that someone who suffers from obesity will experience a decrease in pancreatic cell function. The table shows the $p$-value $=$ 0.000 . This means that there is a significant relationship between BMI and the incidence of diabetes mellitus in people aged 26-45 years in DKI Jakarta.

Research conducted by Devy (2017) shows that there is a correlation between BMI and blood sugar levels, where the greater the value of the BMI calculation results, the higher a person's blood sugar level. Andyana et al. (2020) explained that someone who suffers from obesity will experience a decrease in pancreatic cell function.

Early in the development of diabetes mellitus, pancreatic B cells show impaired insulin secretion that fails to compensate for insulin resistance. If not treated properly, there will be damage to pancreatic B cells. Damage to pancreatic B cells will occur progressively, often 
leading to insulin deficiency, so that eventually patients require exogenous insulin (Noor, 2015).

\section{Abdominal Circumference with The Incidence of Diabetes Mellitus}

Table 9 Relationship of Abdominal Circumference in Men and The Incidence of Diabetes Mellitus

\begin{tabular}{lccc}
\hline \multirow{2}{*}{ Nutritional Status } & \multicolumn{2}{c}{ Diabetes Mellitus } & \multirow{2}{*}{ p value } \\
\cline { 2 - 3 } & Yes & No & \multirow{2}{*}{0,00} \\
\hline Normal & 8.476 & 1.315 .140 & 503.004 \\
Central Obesity & 6.321 & . & \\
\hline
\end{tabular}

Based on table 9, results of the p-value $=0.000$. This shows that there is a significant relationship between abdominal circumference in men and the incidence of diabetes mellitus in people aged 26-45 years in DKI Jakarta Province. These results are in line with research conducted by Affisa, 2018 which states that there is a relationship between obesity and the incidence of diabetes mellitus in men

Obesity that occurs in men is usually known as apple shape obesity, android type obesity or central obesity. This type of obesity has more fat accumulation in the upper body, around the neck, shoulders, chest and face. Obesity is afactor predisposing for insulin resistance, namely, the amount of fat tissue in the body will affect resistance to insulin action, especially if fat accumulates in the abdominal or central area (Clare-Salzler, 2012).

Based on table 10 , results of the $p$-value $=0.000$. This shows that there is a significant relationship between abdominal circumference in women and the incidence of diabetes mellitus in people aged 26-45 years in DKI Jakarta. Research conducted by Pratiwi, Lubis and Mutiara (2018) stated the same results, namely as many as 27 people (51.9\%) of women with diabetes mellitus were obese.

Obesity in women is known as pear shape obesity, gynoid type obesity or peripheral obesity. Fat accumulation in this type of obesity is found in the lower body, which is around the hips, abdomen, buttocks and thighs. Fat in the lower body is relatively safer, because most of what is stored is unsaturated fat (Supriyanto). Therefore, obesity in this type has a lower risk of suffering from diabetes mellitus (Pratiwi et al., 2018).

Based on the results of statistical data processing from the two tables above, it can be concluded that the prevalence of central obesity in women is higher than in men. Research conducted by Farida et al. (2011) showed that central obesity based on abdominal circumference had a greater role than obesity based on BMI.

Table 10 Relationship of Abdominal Circumferene in Women and The Incidence of Diabetes Mellitus

\begin{tabular}{lccc}
\hline \multirow{2}{*}{ Nutritional Status } & \multicolumn{2}{c}{ Diabetes Mellitus } & \multirow{2}{*}{$\boldsymbol{p}$ value } \\
\cline { 2 - 3 } & Yes & No & \\
\hline Normal & 9.631 & 720.252 & 0,00 \\
Central Obesity & 16.462 & 978.230 & \\
\hline
\end{tabular}

\section{CONCLUSION}

The conclusion obtained in the study is the results of theanalysis of the characteristics of the respondents, the respondents totaled 3.557.517 people. Respondents suffering from diabetes mellitus based on doctor's diagnosis amounted to 40892 respondents $(1,1 \%)$ with a higher number of female respondents suffering from diabetes mellitus. The three variables have a significant relationship with the incidence of diabetes mellitus. In the age 
variable, it shows that late adulthood is more susceptible to diabetes mellitus and in BMI respondents in the obese nutritional status category suffer more from diabetes mellitus and in the abdominal circumference variable based on gender, the results show that women in the central obesity category suffer more from DM than the normal category.

\section{CONFLICT OF INTEREST}

The authors declare that there were no conflicts of interest in this study.

\section{ACKNOWLEDGEMENT}

The author would like to thank the Laboratory of Management and Data Analysis of the Ministry of Health Republic of Indonesia in helping to provide the data needed by the author and the Nutrition Study Program of the Faculty of Health Sciences, University of Pembangunan Nasional Veteran Jakarta, who have helped this research so that it can be carried out properly and smoothly.

\section{REFERENCES}

Adnan M. Mulyati T. dan Isworo JT (2013). " Hubungan Indeks Massa Tubuh (IMT) Dengan Kadar Gula Darah Penderita Diabetes Mellitus (DM) Tipe 2 Rawat Jalan Di RS Tugurejo Semarang", Jurnal Gizi Universitas Muhammadiyah Semarang, 2(1).

American Diabetes Association. (2019) "Standards of Medical Care in Diabetes-2019", Diabetes Care. 2019;38(Sppl 1).

Adwina MD and Srimiati M (2019). "Hubungan Lingkar Perut, Konsumsi Gula dan Lemak dengan Kadar Glukosa Darah Pegawai Direktorat Poltekkes Kemenkes Jakarta II" Nutrire Diaita, 31(1).

Amir, S.M.J., H. Wungouw dan D. Pangemanan. (2015) “Kadar Glukosa darah Sewaktu Pada Pasien Diabetes Mellitus Tipe 2 Di Puskesmas Bahu Kota Manado", Jurnal eBiomedik (eBM), 3(1).

Christine Evelyn, S., dkk (2020) "Hubungan Konsumsi Fastfood, Makanan/Minuman Manis dan Aktifitas Fisik dengan Kadar Gula Darah dan Status Gizi Mahasiswa Fakultas Kedokteran Universitas Sam Ratulangi", Indonesian Journal of Public Health and Community Medicine, 1(4).

Clare-salzler, MJ., James, MC., dan Vinay, K. (2012) “Buku Ajar Patologi Robbins”, Penerbit Buku Kedokteran EGC, Edisi 7, Vol 2.

Difriani, P. (2017) "Hubungan Pola Makan dan Aktifitas Fisik Terhadap Kejadian Diabetes Melitus di Poliklinik Penyakit Dalam RSUD dr. Rasidin Padang", NERS Jurnal Keperawatan, 13(2).

Dinas Kesehatan DKI Jakarta (2017). Profil Kesehatan Provinsi DKI Jakarta Tahun 2017. Available from:https://dinkes.jakarta.go.id/wp-content/uploads/2019/12/PROFILKESEHATAN-DKI-JAKARTA-TAHUN-2017.pdf [Retrieved 6 Februari 2021]

Fatimah, R. N. (2015) “Diabetes Melitus Tipe 2”, J Majornity, 4(5). 
Hairuni, N. dan Nugroho, P. S. (2019) “Hubungan Indeks Massa Tubuh (IMT) Dan Lingkar Perut Dengan Kejadian Diabetes Melitus Di Wilayah Kerja Puskesmas Palaran Kota Samarinda Tahun 2019", Borneo Student Research.

I Made Widastra., dkk. (2015) "Obesitas Sentral Sebagai Faktor Penyebab Timbulnya Resistensi Insulin Pada Orang Dewasa”, Jurnal Skala Husada, 12(2):103-109.

Kekenusa et al. (2013) "Analisis Hubungan Antara Umur dan Riwayat Keluarga Menderita DM dengan Kejadian Penyakit DM Tipe 2 Pada Pasien Rawat Jalan di Poliklinik Penyakit Dalam BLU RSUP Prof. Dr. R.D Kandou Manado", Universitas Sam Ratulangi Manado, Available from:https://fkm.unsrat.ac.id/wpcontent/uploads/2013/08/GLORIA-WUWUNGAN-091511080.pdf[Retrieved 9 Februari 2021]

Kementrian Kesehatan RI. (2019) “Laporan Nasional RISKESDAS 2018”, Lembaga Penerbit Badan Penelitian dan Pengembangan Kesehatan.

Komariah, dan Sri Rahayu. (2020) "Hubungan Usia, Jenis Kelamin, dan Indeks Massa Tubuh dengan Kadar Gula Darah Puasa Pasien Diabetes Mellitus Tipe 2 di Klinik Pratama Rawat Jalan Proklamasi, Depok, Jawa Barat", Jurnal Kesehatan Kusuma Husada, Januari 2020.

Noor, Restyana. (2015) “Diabetes Mellitus Tipe 2”, J Majornity, 4(5), hlm 93-101.

Nur, A. Fitria, E., dkk. (2016) "Hubungan Pola Konsumsi dengan Diabetes melitus Tipe 2 pada Pasien Rawat Jalan di RSUD Dr. Fauziah Bireuen Provinsi Aceh", Media Litbangkes, 26(3).

Pahlawati, A., dan PS, Nugroho. (2019) "Hubungan Tingkat Pendidikan dan Usia dengan Kejadian Diabetes Mellitus di Wilayah Kerja Puskesmas Palaran Kota Samarinda Tahun 2019", Borneo Student Research.

Perkeni 2015, Konsesnsus Pengelolaan dan Pencegahan Diabetes mellitus Tipe 2 Di Indonesia 2015, PB Perkeni, Available from:https://pbperkeni.or.id/wpcontent/uploads/2019/01/4.-Konsensus-Pengelolaan-dan-Pencegahan-Diabetesmelitus-tipe-2-di-Indonesia-PERKENI-2015.pdf [Retrieved 6 Februari 2021]

Prasetyani, D., dan Sodikin. (2017) “Analisis Faktor Yang Mempengaruhi Kejadian Diabetes Mellitus (DM) Tipe 2", Jurnal Kesehatan Al Irsyad (JKA), X(2).

Pratiwi, et al. (2018) "Pengaruh Obesitas terhadap Kejadian Diabetes Mellitus pada Wanita Usia Subur di RSUD. Dr. Djoelham Binjai Tahun 2017”, Journal of Healhcare Technology and Medicine, 4(1).

Rabrusun, A. N. (2014) “Hubungan Antara Umur Dan Indeks Massa Tubuh Dengan Kejadian Diabetes Mellitus Tipe 2 Di Poliklinik Interna BLU RSUP Prof. Dr. R. D. Kandou Manado", FKM Unstrat.

Sa'pang, M., Puili, D. and Sitoayu, L. (2018) “Hubungan Indeks Massa Tubuh (IMT) Dan Rasio Lingkar Pinggang Pinggul (RLPP) Dengan Kadar Glukosa Darah Puasa Pada Penderita Diabetes Melitus Tipe II Di Puskesmas Kebayoran Lama, Jakarta Selatan", Nutrire Diaita, 10(1).

Sirait, et al. (2015) "Insiden dan Faktor Resiko Diebetes Mellitus Pada Orang Dewasa di Kota Bogor. Studi Kohor Prospektif Faktor Resiko Penyakit Tidak Menular", Buletin Penelitian Sistem Kesehatan, 18(2), hlm 151-160.

Soelistijo, A. S., dkk. (2015) “Konsensus Pengelolaan Dan Pencegahan Diabetes melitus Tipe 2 Di Indonesia 2015”, PB PERKENI. 
Soelistijo, A. S., dkk. (2019) "Pedoman Pengelolaan Dan Pencegahan Diabetes Melitus Tipe 2 Dewasa Di Indonesia 2019”, PB PERKENI.

Sumangkut, S., Supit, W., and Onibala, F. (2013) "Hubungan Pola Makan Dengan Kejadian Penyakit Diabetes Mellitus Tipe 2 Di Poli Interna BLU RSUP Prof. Dr. R. D. Kandou Manado", eJournal Keperawatan, 1(1).

Sutanto, PH. (2016) “Analisis Data Pada Bidang Kesehatan”, PT Rajagrafindo Persada, Cetakan ke-1.

Wijiaya, A., N.Wade dan I.A.P. Wirawati. (2019) "Hubungan Lingkar Perut dengan Kadar Gula Darah Puasa pada Mahasiswa Fakultas Kedokteran Universitas Udayana Angkatan 2014", Intisari Sains Medis, 10(2) : 279-283. 